\title{
THE LARGER ASPECTS OF THE WOMAN'S MOVEMENT
}

\author{
By Jane Addams, \\ President, Hull-House Association, Chicago.
}

Perhaps no presentation of history is so difficult as that which treats of the growth of a new consciousness; but assuming that the historic review, now so universal in the field of social judgment and investigation, is applicable to any current development, I have ventured to apply it to that disturbing manifestation called the "votes-for-women" movement, which at the present moment is not only the centre of hot debate but, unhappily, also of conduct which in the minds of many is most unseemly.

Because I shall need the indulgence of the reader who may kindly follow this review, I will at once recall to his mind the statement of an ironic Englishman that it would be better to be convicted of petty larceny than to be found wanting in historic mindedness.

To begin then with the world-wide aspect of the votes-for-women movement-that there may be nothing more petty about us than the theme itself imposes-it is possible to make certain classifications of underlying trends, which, while not always clear, and sometimes overlapping, are yet international in their manifestations.

First: the movement is obviously a part of that evolutionary conception of self-government which has been slowly developing through the centuries. For the simple reason that self-government must ever be built up anew in relation to changing experiences, its history is largely a record of new human interests which have become the object of governmental action, and of the incorporation into the body politic of the classes representing those interests. As the governing classes have been enlarged by the enfranchisement of one body of men after another, government itself has not only become enriched through new human interests, but at the same time it has become further democratized through the accession of the new classes representing those interests. The two propositions are complementary.

When the middle classes in every country in Europe struggled to wrest governmental power from the exclusive grasp of the nobles, 
the existing governments were already concerned with levying tariffs and embargoes, and the merchants insisted, not only that the problems of a rising commerce could not be settled by self interested nobles, but that they themselves must have direct representation before those problems could even be stated intelligently.

When the working men of the nineteenth century, the chartist in England and "the men of forty-eight" in Germany, vigorously demanded the franchise, national parliaments had already begun to regulate the condition of mines and the labor of little children. The working men insisted that they themselves could best represent their own interests, but, at the same time, their very entrance into government increased in volume the pressure of those interests.

In certain aspects, the entrance of women into government differs from former efforts in the extension of the franchise. We recall that the final entrance of the middle class into government was characterized by two dramatic revolutions, one in America and one in France, neither of them without bloodshed. This worldwide entrance into government on the part of women is happily a bloodless one and has been without a semblance of violence save in England where its manifestations are not unlike those of the earlier movement among English workingmen. Throughout those efforts so to change political institutions that they might effectively give expression to the growth of new experiences, the dependence of the political machine for its driving force upon the many varieties of social fuel constantly was made clear. It was, after all, rather an astute statesman who remarked that "What liberty and prosperity depend upon are the souls of men." Certain it is that the phenomenal entrance of woman into governmental responsibilities in the dawn of the twentieth century is co-incident with the consideration by governmental bodies of the basic human interests with which women have traditionally been concerned, quite as the membership of the middle class and that of the working class each in turn followed its own interests and became a part of representative government.

The new demand of women for political enfranchisement comes at a time when unsatisfactory and degraded social conditions are held responsible for so much wretchedness and when the fate of all the unfortunate, the suffering, and the criminal, is daily forced upon woman's attention in painful and intimate ways. At the same 
moment, governments all over the world are insisting that it is their function, and theirs alone, so to regulate social and industrial conditions that a desirable citizenship may be secured.

In certain respects the insistence of women for political expression, which characterizes the opening years of the twentieth century, bears an analogy to their industrial experiences in the early part of the nineteenth century, when the textile industries were taken out of private houses and organized as factory enterprises. If women had not followed those old industries into factories, thousands of them would have sat idly at home in empty houses, losing not only the money they had formerly earned but their old occupation as well. It was often considered "unwomanly" for these spinsters to go outside the home in order to use a spindle driven by steam power, possibly because all the queens of polite history, since the days of Penelope, when interrupted by their amours were always languidly engaged with textiles. It is hard to see now how the basic industry of England could have been developed without the thousands of women and girls who in spite of public opprobrium followed their old occupations.

But is it not obvious that, as industrial changes took spinning out of private houses, so political changes are taking out of the home humanitarian activities, not to mention the teaching of children? The aged poor of a community who were formerly cared for in the houses of distant relatives or old neighbors, the sick who were nursed night and day by kindly friends and acquaintances taking turn and turn about, are now housed in large infirmaries and in hospitals built and supported by the tax payers' money. The woman who wishes to be a teacher or a nurse takes her training in public institutions, as she formerly went to the factory to spin, not because she wishes primarily to leave home but because her work has been transferred. As she was helpless, without the franchise, to keep little children from working all night in the early textile mills of Yorkshire, so she is powerless now to regulate the administration of schoolhouse or hospital. A college woman who was recently appointed dietitian for the institutions of Cook County found that the menu in essential respects had not been changed in thirty-two years because it was easier for the county commissioners to copy the old forms upon which the food contracts had been awarded than to make new ones. 
Studied from a second aspect, the "votes-for-women" movement is doubtless one result of the fundamental change which is taking place in the conception of politics analogous to the changes in the basic notions in education, criminology, and political economy. Graham Wallas, in his very interesting book Human Nature in Politics, points out that, while educators have learned to study child psychology so that teachers understand children rather than manage schools, and that while jurists are ceasing to classify offenders solely on the basis of their crimes and are beginning to regard them as human beings, politicians have not yet learned to apply social psychology to the field of political action. The individual voter is still regarded as a party adjunct, a useful unit for party organization exactly as the old economist long considered the "economic man" as a sort of lone wolf impelled by no other motive than the desire for food. Quite as the science of political economy made little progress until it got rid of that fiction and looked at men as they really exist, each a bundle of complicated and overlapping motives, so politicians are making many blunders because their action is not founded upon the genuine facts of human existence. They have failed to observe how rapidly the materials and methods of political life are changing, that the law courts and legislature are struggling desperately to meet modern demands with conceptions of property and authority and duty founded upon the rude compromises made centuries ago, that there is obvious need for bolder arrangements and interactions in the distribution of employment, education, invention. Such changes can only come about if they are carried on with that same spirit of free thinking and outspoken publication that has won in the field of natural science.

An able man long ago pointed out that the qualities most valuable in an electorate are social sympathies and a sense of justice, then openness and plainness of character, lastly habits of action and a practical knowledge of social misery. Woman's value to the modern states, which constantly are forced to consider social reforms, lies in the fact that statesmen at the present moment are attempting to translate the new social sympathy into political action.

The contemporary efforts to extend the principles of social insurance to illness in several European states, and to control unemployment through national labor exchanges, are not so much social reforms as titanic pieces of social engineering in which the judgment 
of women is most necessary. Governmental commissions everywhere take woman's testimony as to legislation for better housing, for public health and education, for the care of dependents, and many other remedial measures, because it is obviously a perilous business to turn over delicate social experiments to men who have remained quite untouched by social compunctions and who have been elected to their legislative position solely upon the old political issues. Certainly under this new conception of politics it is much easier to legislate for those human beings of whose condition the electorate are "vividly aware," to use a favorite phrase of Professor James.

It is not difficult to find instances in which legislators have made themselves a little absurd by ignoring this philosophic postulate. A most advanced German statesman in the reichstag declared recently that it was a reproach to the imperial government that out of two million children born annually in Germany four hundred thousand died during the first twelve months of their existence. He proceeded to instance various reforms which might remedy this, such as better housing, the increase of park areas, the erection of municipal hospitals, the provision for adequate milk supply and many another, but he did not make the very obvious suggestion that the advice of women might be valuable in the care of children less than two years old. Nor did the English Farliament see the connection when they spent an entire evening discussing the propriety of prohibiting the use of a popular brand of flannelette for children's night gowns because so many tenement house babies had been burned to death when lighted candles held by weary mothers came in contact with the inflammable material whose smooth finish had been superinduced by an industrial process in which turpentine was used. The House was hotly divided as to whether the use of wool was absolutely necessary to the health of young children, although the members of the party, advocating "cottonette" as a substitute, were somewhat chagrined when upon consulting their wives at breakfast the next morning they found that the word had been coined in the heat of argument and that there was no such material on the market. During the last presidential election in the United States, when measures of social reform suddenly became the basis of party pledges, many women were pushed into the stream of party politics with a momentum almost as instinctive as that of a mother who springs into the water to 
rescue her child. Naturally when women see their social causes, some of them tiny things and new born, about to be turned over to governmental officials, they insist upon an opportunity to help select the men who are to become the protagonists of their most cherished reforms.

Women have discovered that the unrepresented are always liable to be given what they do not need by legislators who wish merely to placate them; a child labor law exempts street trades, the most dangerous of all trades to a child's morals; a law releasing mothers from petty industry that they may rear worthy children provides a pension so inadequate that over-burdened women must continue to neglect their young in order to feed them.

More than one woman, while waiting in the lobby for an opportunity to persuade recalcitrant law-makers in regard to a legislative measure, has had ample time to regret that she had no vote by which to select the men upon whom her social reform had become so absolutely dependent. Such a woman can even recall some cherished project which has been so modified by uninformed legislators during the process of legal enactment that the law finally passed injured the very people it was meant to protect.

The community, for instance, will never be made "vividly aware" of the effects of chronic fatigue upon young working girls or upon children who divert their energy from growth to pasting labels on a box by men whose minds are fixed upon factory management from the point of view of profits. The cultural outlook on life must become as aggressive as the commercial if it hopes to be effective.

The third trend in the feminist movement might be called evolutionary rather than historic, if indeed the two may be separated. In this trend the very earliest stage is doubtless represented by those women of Asia who are making their first struggle against the traditional bondages and customs whose roots creep back into primitive times, and whose efforts are yet in that incipient and unorganized stage which characterized the efforts of western women a hundred years ago. As a whole, this trend is connected with contemporary revolutions carried on by men demanding a direct representation in governments which at present ignore them. The most striking example, perhaps, is Russia, where women have taken an active part in the recently established constitutional government. 
Twenty-one of them at the present moment are sitting as members in the Finnish Parliament. Due to that inveterate tendency of revolutionists to incorporate into their program the most advanced features of existing governments, the demand for woman's political representation has reached even Mohammedan countries, such as Persia and Turkey, where it is directly opposed to their religious teaching. Both China and Siam, in spite of eastern customs, have given women a political status in their new constitutions by extending to certain classes of them the right of suffrage.

In contrast to these contemporary revolutions in which women have been recognized are the European revolutions of the nineteenth century in which women also worked side by side with men for a larger democracy, but where they were ignored when the constitutions were finally written. This is clearly seen in such states as Bohemia, Silesia, and Hungary, where women with certain property qualifications are still sending members to Parliament who directly represent their interests. This right of women to vote has survived from the days when the ownership of property was the only basis upon which either men or women were given the franchise. When the vote for men was based upon a broader qualification than that of property, the vote, although it was not extended to other women, was not taken away from the women previously qualified. It was upon such a basis that women a few centuries ago sat in the English Parliament and at this moment are voting upon the same terms as men in the municipal governments of Rangoon and other Indian cities. These surviving votes, representing a stage long past, are a reproach to existing governments which at the present moment are making a greater disparity between the political status of men and women than that which existed three hundred years ago. Whatever the result, in the final adjustment, so long as the revolutions both of the nineteenth and the twentieth century were purely inspirational and doctrinaire, the revolutionists recognized the equality of women. The aftermath was obvious, during the recent election in Chicago, that the women of those nations recently stirred by revolution were the women most eager to utilize the franchiseBohemian, Polish, and Irish women, and the Italian women whose families had been committed to a new Italy.

The generous moral feeling evoked in a time of revolution, reducing life to its first principles as it were, tends to restore women 
to their earlier place in society, somewhat as women regain much of their original social importance in pioneer countries where there is little division of labor. Because good government is not a matter of sex when it means a method of identifying cattle which have become mixed with the neighboring herd or of defending little children from the dangers incident to frontier life, it has evidently been difficult for the pioneer man to withhold political rights from women when government has become more conventional. Such a condition is represented by all of the Australian states, one following another in the granting of the franchise to women until the entire seven are included; by Wyoming which gave suffrage to women in 1869 , and by others of the western states in America, and last of all by Alaska. Even the conservative Boers of the early Dutch republics in South Africa had given the right of the franchise to the women who had trekked and fought and ploughed by their sides in the spirit of the early German woman who evoked the admiration of Tacitus. And although the Dutch women had never used the vote, being inhibited by some notion that it was not ladylike, there it was ready at hand until the English inaugurated a more sophisticated rule.

The final impression of a review of this movement we have ventured to consider is of a cause growing, pushing, and developing in all the nations upon the face of the earth, representing new experiences and untrammeled hopes. It is everywhere surprisingly spontaneous and universal. It not only appears simultaneously in various nations in both hemispheres, but manifests itself in widely separated groups within the same nation, embracing the smart set and the hard driven working woman; sometimes the movement is sectarian and dogmatic, at others philosophic and grandiloquent; it may be amorphous and sporadic, or carefully organized and consciously directed; but it is always vital and is constantly becoming more widespread. 